\title{
ENHANCE THERMAL EFFICIENCY OF PARABOLIC TROUGH COLLECTOR USING TUNGSTEN OXIDE/SYLTHERM 800 NANOFLUID
}

\author{
${ }^{1}$ Otabeh AL-ORAN ${ }^{*}{ }^{2}$ Ferenc LEZSOVITS \\ ${ }^{1,2}$ Department of Energy Engineering, Faculty of Mechanical Engineering \\ Budapest University of Technology and Economics, 1111 Budapest, Müegyetem rkp.3 \\ Hungary, e-mail: ${ }^{1}$ aloran@energia.bme.hu, ${ }^{2}$ lezsovits@energia.bme.hu
}

Received 11 November 2019; accepted 27 January 2020

\begin{abstract}
Development of thermal efficiency of the concentrated solar energy especially parabolic trough collector using various nanofluids types has a taken high interest in recent years. In this article enhancement thermal performance inside the heating collecting element of trough collector type LS-2 was simulated and improved using nanofluid consist of Tungsten Oxide $\mathrm{WO}_{3}$ inserting in Syltherm 800. Nanofluid effect was examined by solving the energy balance equation using MATLAB Software to cover wide range concentration volume 1-5\% and inlet temperatures ranging from $350-650 \mathrm{~K}$ for the turbulent flow. The heat transfer performance and thermal efficiency were improved based on the results, and a notable increase was obtained when volume concentration had been increased compared with base fluid.
\end{abstract}

Keywords: Parabolic trough collector, Solar energy, Nanofluid, Thermal efficiency, Enhancement

\section{Introduction}

Growing attention of the pollutant issues, climate change problems in addition to the shortage that occurs on fossil fuel resulted by rising of the consumption contributed to accelerating the needed to replace and search on the clean and alternative types of energy [1]. Solar energy has gained more interest compared to other renewable energy sources like wind energy and biomass energy. Whereas this clean energy plays an essential role in the mitigation of the economic burden particularly for the sunny regions like Jordan [2]. Study solar intensity effect on various collectors' types in any region

${ }^{*}$ Corresponding Author 
demands deep knowledge on how defined various geometrical variables vary with the sun position [3]. Parabolic Trough Collector (PTC) is considered as one of the most typical concentrated solar power devices, which is used widely to produce high and medium temperatures coinciding with high efficiencies [4]. Developing PTC to be more effective and efficient has been reached using various passive and active techniques. These techniques aimed to enhance heat transfer and the ability of fluid to carry focusing rays and decrease heat loss from the heating collecting of the PTC [5]. Recently, inserting metallic and oxides particles that have a small diameter measured in nanoscale in various base fluids took high interest as an enhancement technique called nanofluid [6]-[8]. The effect of using this technique was examined experimentally and numerically using various nanoparticles and base fluids in different scientific researches. The founding results of these researches showed a varying enhancement in the most researches while few pieces of research did not show an increase in the thermal efficiency [9]. Different of the experimental works examined various nanoparticles namely $\left(\mathrm{Al}_{2} \mathrm{O}_{3}, \mathrm{TiO}_{2}, \mathrm{Fe}_{2} \mathrm{O}_{3}, \mathrm{MWCNT}, \mathrm{CuO}, \mathrm{SiO}_{2}\right.$, Nano silica, $\left.\mathrm{Ag}\right)$ in various places of the world and under various conditions. In addition, these researchers examined the mentioned nanoparticles with different base fluids (i.e. water, Ethylene Glycol (EG) and oil). Finally, these examined tests were affected by the different volume or weight concentrations and variable mass or volume flow-rate [10]-[12]. The numerical side took more attention compared to experimental works; for this side defined and solved energy equation of the heat collecting element under various conditions, which was simulated using different programs like using Computational Fluid Dynamics (CFD) [13]. Other simulation programs can be used like engineering equation solver, MATLAB, and Solid Works also were used widely to simulate thermal efficiency and heat transfer performance resulted by inserting different nanofluids. In Table $I$ the researches that used various nanoparticles with oil as a base fluid were presented in addition to the main founding enhancement results and main parameters of PTC and the receiver pipe [14]-[20].

From Table $I$ the commercial PTC type LS2 has a larger number of researches compared to other commercial and domestic types, according to the available experimental results data under wide range conditions can be used to validate simulation results [21]. Various nanoparticle types were simulated with high interest for that using $\mathrm{Al}_{2} \mathrm{O}_{3}$ compared to other nanoparticles. Moreover, it showed variable enhance between the same nanoparticles and others referred to different aspects like types of the parabola and receiver, type of the nanoparticles, concentrations. Finally, most mentioned research showed enhancing, except some of them that showed negligibly improve [18], [20].

According to the literature there is no research that examined the effect of using Tungsten oxide $\mathrm{WO}_{3} /$ Syltherm 800 nanofluid as a heating fluid flow inside the receiver of PTC. So this article aimed at examining the ability of this modified fluid to enhance the thermal efficiency of the parabola type LS2 by solving the thermal balance energy equation using MATLAB code. Moreover, this article aimed at compared thermal efficiency, convective heat transfer coefficient, and Nusselt number that resulted by various volume concentration ranging $1-5 \%$, and wide inlet temperature ranges from 350-650 K. Finally, the radiation intensity that was used through this research was taken as a constant equal maximum value. This maximum value was produced by presenting 
the radiation intensity using ASHRAE model for typically sunny day of Jordan under geographical location $31 .{ }^{\circ} 57^{\prime} \mathrm{N} / 35^{\circ} 55^{\prime} \mathrm{E}$.

\section{Table I}

Thermal performance enhancements of PTC using nanofluid technique

\begin{tabular}{|c|c|c|c|c|c|}
\hline \multirow{2}{*}{ Ref } & \multirow{2}{*}{$\begin{array}{c}\text { PTC } \\
\text { Model } \\
\mathrm{L}, \mathrm{W} \\
\mathrm{d}_{\mathrm{o}}, \mathrm{d}_{\mathrm{i}} \\
\mathrm{mm}\end{array}$} & Nanofluid & \multicolumn{3}{|c|}{ Max, Increase\% } \\
\hline & & Nanoparticle-base fluid & $\begin{array}{c}\varphi \\
\operatorname{Max}\end{array}$ & $\eta_{\text {eff }}$ & h \\
\hline [14] & $\begin{array}{l}(2,0.7) \\
(28,26)\end{array}$ & MWCNT -Thermal-oil & $6 \% . v$ & 49.58 & $15 \%$ \\
\hline [15] & LS2 PTC & $\begin{array}{c}\mathrm{Tio}_{2}, \mathrm{Al}_{2} \mathrm{O}_{3} / \text { Hybrid-Syltherm } \\
800\end{array}$ & $3 \% \mathrm{v}$ & $\begin{array}{l}\text { Mono } 0.7 \% \\
\text { Hyb } 1.8 \%\end{array}$ & $\begin{array}{c}\text { Mono } \\
1.35 \% \\
\text { Hyb } 2.4 \% \\
\end{array}$ \\
\hline [16] & LS2 PTC & $\begin{array}{c}\mathrm{CuO}, \mathrm{Cu}, \mathrm{Fe}_{2} \mathrm{O}_{3}, \mathrm{TiO}_{2}, \mathrm{Al}_{2} \mathrm{O}_{3}, \\
\mathrm{SiO}_{2} \text {-Syltherm } 800\end{array}$ & $6 \% \mathrm{v}$ & $\mathrm{Cu} 2.2 \%$ & $\sim 24 \%-\mathrm{Cu}$ \\
\hline [17] & LS2 PTC & $\begin{array}{l}\mathrm{CuO}, \mathrm{Cu}, \mathrm{Ag}, \mathrm{Al}_{2} \mathrm{O}_{3^{-}} \\
\text {Syltherm } 800\end{array}$ & $5 \% \mathrm{v}$ & - & $36 \% \mathrm{Ag}$ \\
\hline [18] & $\begin{array}{c}100,5.5 \\
(-, 65)\end{array}$ & $\mathrm{Al}_{2} \mathrm{O}_{3}$-Synthetic-oil & $5 \% \mathrm{v}$ & $\sim 0$ & $53.5 \%$ \\
\hline [19] & $\begin{array}{l}\text { Euro } \\
\text { Trough }\end{array}$ & $\mathrm{Al}_{2} \mathrm{O}_{3}, \mathrm{CuO}$-Syltherm 800 & $4 \% \mathrm{v}$ & $\begin{array}{c}\mathrm{Max} \mathrm{CuO} \\
1.26 \%\end{array}$ & $\sim 45 \%$ \\
\hline$[20]$ & $\begin{array}{l}(5,1.5) \\
(40,65) \\
\end{array}$ & $\begin{array}{c}\mathrm{CuO}, \mathrm{TiO}_{2}, \\
\mathrm{Al}_{2} \mathrm{O}_{3}, \mathrm{SiO}_{2} \text {-mineral oil }\end{array}$ & $5.5 \%$ & $\sim 0$ & - \\
\hline
\end{tabular}

\section{Model specification}

To convert concentrated radiation on the heat collecting element of PTC high reflective mirrors were designed on a parabola shape as shown in Fig. 1 to enhance the temperature of the Thermal Fluid (TF), which leads to enhancement of thermal efficiency. The receiver part nowadays is covered with a glass envelope and coated with high absorptivity material to minimize heat losses and to improve heat transfer to TF flow inside the receiver.

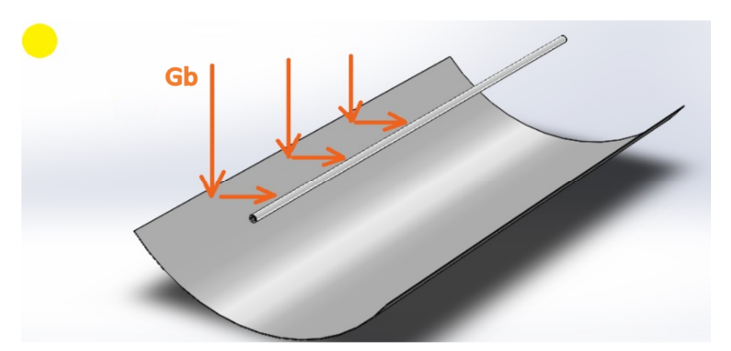

Fig. 1. Conceptual parabolic trough collector 
Parabolic trough model type LS2 developed and analyzed under maximum level radiation intensity of Jordan as a case study and $\mathrm{WO}_{3} /$ Syltherm 800 nanofluid. The heating element of this model was described as a one-dimensional, where the energy balance equations solved numerically using MATLAB software. Actually, all the dimensions and parameters of this PTC type used in this work were taken as summarized in [15], as presented in Table II.

Table II

Main parameters and dimensions [15]

\begin{tabular}{|l|l|l|l|}
\hline LS-2 Parameter [Symbols] & $\begin{array}{l}\text { Specifica- } \\
\text { tions }\end{array}$ & Parameter [Symbols] & $\begin{array}{l}\text { Specifica- } \\
\text { tions }\end{array}$ \\
\hline Length of the PTC $[L]$ & $7.8 \mathrm{~m}$ & Emittance of glass cover $\left[\varepsilon_{c}\right]$ & 0.9 \\
\hline $\begin{array}{l}\text { Aperture Width of the } \\
\text { PTC }\left[W_{\mathrm{a}}\right]\end{array}$ & $5 \mathrm{~m}$ & Incident Angle $[\theta]$ & 0 \\
\hline Aperture Area $\left[A_{\mathrm{a}}\right]$ & $39 \mathrm{~m}^{2}$ & Max optical efficiency $\left[\eta_{o p t}\right]$ & $74.5 \%$ \\
\hline Focal length $[F]$ & $1.71 \mathrm{~m}$ & Glass cover absorbance $[\alpha c]$ & 0.02 \\
\hline Concentration ratio $[C]$ & 22.74 & Glass cover transmittance $\left[\tau_{c}\right]$ & 0.95 \\
\hline $\begin{array}{l}\text { Absorber inner diameter } \\
{\left[d_{r i}\right]}\end{array}$ & $0.066 \mathrm{~m}$ & Absorber absorbance $\left[\alpha_{r}\right]$ & 0.96 \\
\hline $\begin{array}{l}\text { Absorber outer diameter } \\
{\left[d_{r o}\right]}\end{array}$ & $0.07 \mathrm{~m}$ & Concentrator reflectance $\left[\rho_{c}\right]$ & 0.83 \\
\hline Glass inner diameter $\left[d_{c i}\right]$ & $0.109 \mathrm{~m}$ & Intercept factor $[\gamma]$ & 0.99 \\
\hline Glass outer diameter $\left[d_{c o}\right]$ & $0.115 \mathrm{~m}$ & Emittance of the absorber $[\varepsilon r]$ & 0.2 \\
\hline
\end{tabular}

\subsection{Radiation intensity}

Estimated radiation intensity was defined basing on $15^{\text {th }}$ of July as a typical sunny day of the Jordan, which located under geographical location $31 .^{\circ} 57^{\prime} \mathrm{N} / 35^{\circ} 55^{\prime} \mathrm{E}$ using the ASHRAE model. Basically, this model was based on the following equations to define normal solar beam radiation and diffused radiation in the horizontal surface,

$$
\begin{aligned}
& D N I=A \times e^{\frac{-B}{\cos \theta z}} \\
& I_{d}=C \times D N I .
\end{aligned}
$$

The factors $\left(\mathrm{A}, \mathrm{B}\right.$, and $\mathrm{C}$ ) are equal to $1085,0.207,0.136$, while $\theta_{z}$ describes zenith angel [22]. All the correlations were inserted as subroutine code to define the variation of the solar radiation on the PTC. The results showed maximum radiation of 998.7 W/m ${ }^{2}$ at midday as it is illustrated in Fig. 2.

\subsection{Thermal model}

The main goal of this section was to describe the thermal model inside the receiver tube of the PTC by solving the energy balance equation at different nods by dividing the receiver section into different segments. Through this section, the thermal resistance, heat loss and heat transfer directions from thermal heating fluid and outside have been presented. Study the mode of the heat transfer convection, radiation and conduction at a 
different point of glass through receiver tube until you reach the TF used to describe the heat gained by the system illustrated as it is shown in Fig. 3, which was used to estimate the thermal efficiency as expressed in the following equations (3)-(6) [19].

$$
\begin{aligned}
& \eta_{\text {the }}=\frac{Q_{u}}{Q_{s}} \\
& Q_{u}=m \cdot C_{p}\left(T_{f, \text { out }}-T_{f, \text { in }}\right) .
\end{aligned}
$$

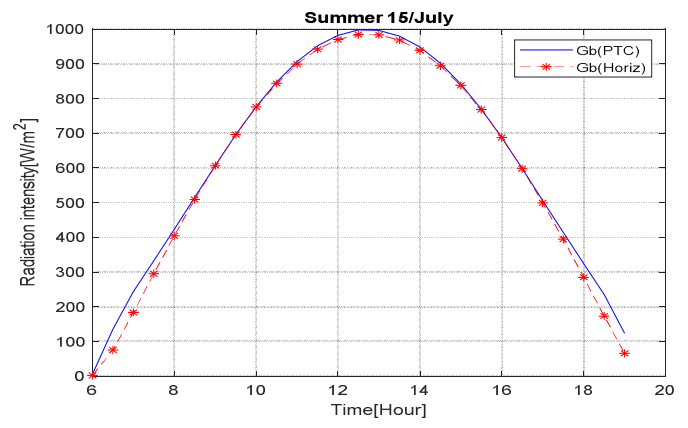

Fig. 2. Total radiation intensity on the PTC and horizontal surface under radiation intensity of Amman
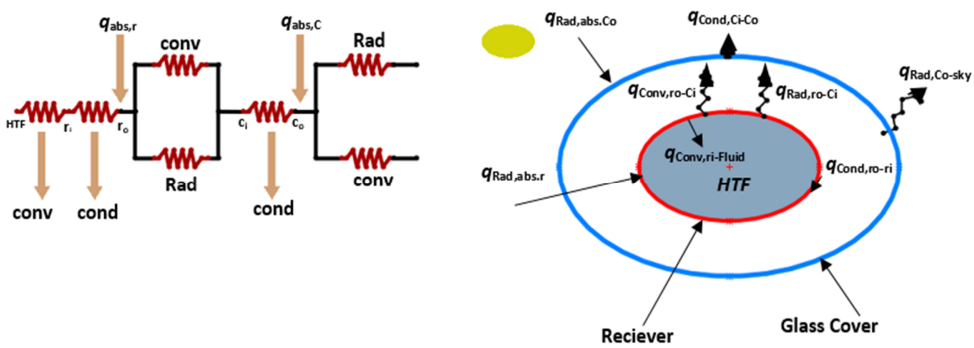

Fig. 3. Evacuated tube receiver and resistance nods

Useful energy $\left(Q_{u}\right)$ can be calculated by multiplying the convection heat transfer coefficient $(h)$ by the temperatures difference between inlet receiver temperature $\left(T_{r i}\right)$, and fluid mean temperature $\left(T_{f m}\right)$, as expressed in the following equation,

$$
Q_{u}=h A_{r i}\left(T_{r i}-T_{f m}\right),
$$

where the sensible heat defined as the amount of intensity beam irradiation $G_{b}$ captured multiplied by the reflected apertures area $A_{a p}$, where equation (6) expressed that

$$
Q_{s}=A_{a p} \cdot G_{b} \text {. }
$$




\subsection{Thermal fluid specifications}

This section summarized the equations and main correlations obtained from literature to describe the thermal properties of the nanofluid. For this research, a modified nanofluid subscribed by ( $n f)$ was obtained by mixing Syltherm- 800 as a base fluid $(b f)$ and Tungsten oxide $\mathrm{WO}_{3}$ nanoparticle subscribed by $(n p)$ to define the density $(\rho)$, specific heat capacity $\left(C_{p}\right)$, thermal conductivity $(k)$ and dynamic viscosity $(\mu)$ that lead enhancement in the thermal efficiency. The effect of using Tungsten oxide nanofluid in the thermal efficiency of PTC was analyzed under variable inlet temperature $350 \mathrm{~K}-650 \mathrm{~K}$, volume fraction $\varphi(1 \%-5 \%)$, and maximum obtained radiation attends to the parabola surface, which is equal to $998.78 \mathrm{~W} / \mathrm{m}^{2}$. The following equations from (7) to (10) were used to define various thermal nanofluid properties [23]-[26],

$$
\begin{aligned}
& \rho_{n f}=(1-\varphi) \rho_{b f}+\varphi \rho_{n p}, \\
& C p_{n f}=\frac{1}{\rho_{n f}}[(1-\varphi)] \rho_{b f} C p_{b f}+\varphi \rho_{n p} C p_{n p}, \\
& k_{n f}=k_{b f}\left[\frac{k_{n p}+2 k_{b f}+2\left(k_{n p}-k_{b f}\right)(1-\beta)^{3} \varphi}{k_{n p}+2 k_{b f}-\left(k_{n p}-k_{b f}\right)(1-\beta)^{3} \varphi}\right], \\
& \mu_{n f}=\mu_{b f} \frac{1}{(1-\varphi)^{2.5}} .
\end{aligned}
$$

Mainly, the correlations that used to cover the thermal properties of Syltherm- 800 as a base fluid were selected from literature, as mentioned by Mwesigye and Huan [27]. While the thermal properties of the nanoparticle presented in Table III were picked, as indicated by Sharafeldin and Gróf, in their research [28].

\section{Table III}

Nanoparticles specifications on the basis of [28]

\begin{tabular}{|l|c|}
\hline Property/Nanoparticles & Tungsten oxide nanoparticle $\mathrm{WO}_{3}$ \\
\hline Specific heat $C p_{n p}(\mathrm{~J} / \mathrm{kg} \mathrm{K})$ & 315.4 \\
Density $\rho_{n p}\left(\mathrm{~kg} / \mathrm{m}^{3}\right)$ & 7160 \\
Thermal conductivity $k_{n p}(\mathrm{~W} / \mathrm{m} \mathrm{K})$ & 16 \\
\hline
\end{tabular}

Thermal efficiency improvement using modified nanofluid of $\mathrm{WO}_{3}$ /Syltherm 800 was simulated by solving thermal energy balance using MATLAB code, where the flow chart in Fig. 4 used to illustrate the procedure, input, and output that were used in this research.

\section{Results and discussions}

A validation of a thermal model using Syltherm- 800 as a base fluid showed high accuracy behavior with the experimental results of the same type of PTC; that was conducted by Dudley [21]. Various thermal efficiency results were illustrated for different conditions as it is shown in Fig. 5 under a mean deviation equal to $1.15 \%$. 
As it has been mentioned before, various inputs are taken as a constant parameter regarding the main aim of this type of research, which aimed to improve the thermal efficiency of PTC using Tungsten oxide nanofluid under variable volume concentration. Regarding the radiation intensity, which was taken as a maximum value of $998.7 \mathrm{~W} / \mathrm{m}^{2}$, while the optimum volumetric flow-rate was taken $150 \mathrm{~L} / \mathrm{min}$ after presenting the relationship between the efficiency and volumetric flow-rate at different temperatures as it is shown in Fig. 6.

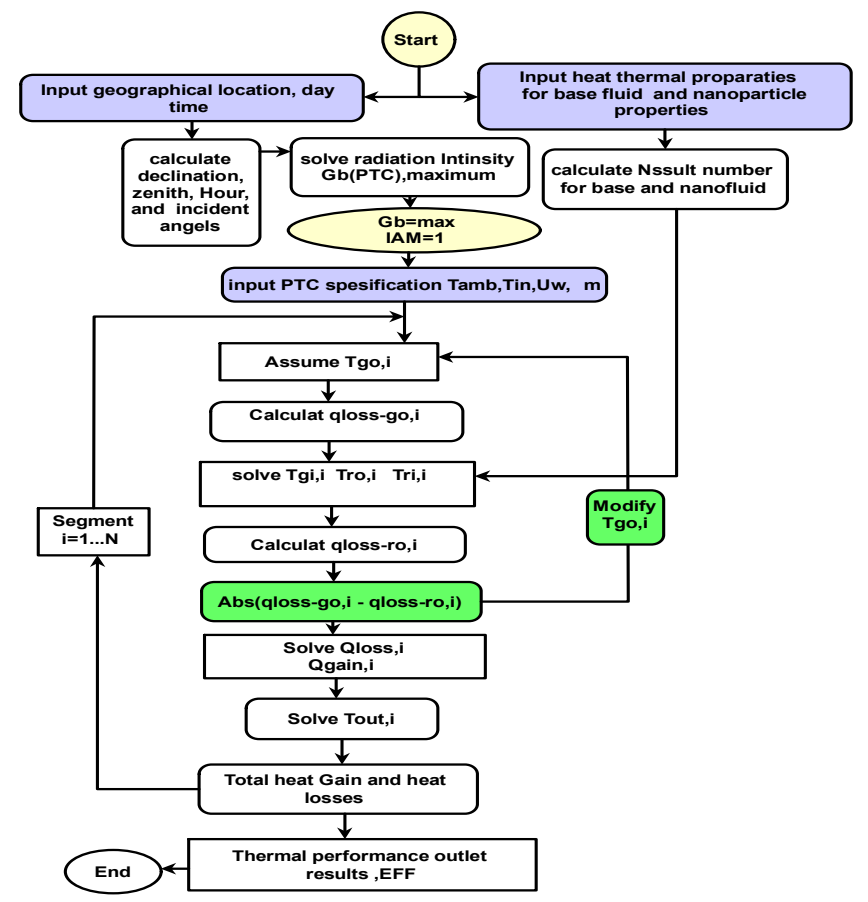

Fig. 4. Simulation model flow chart

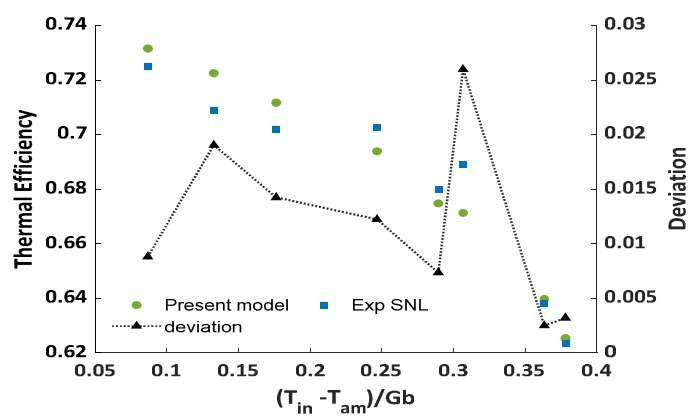

Fig. 5. Comparison between present model with previous experimental results that conducted by Dudley [21] 


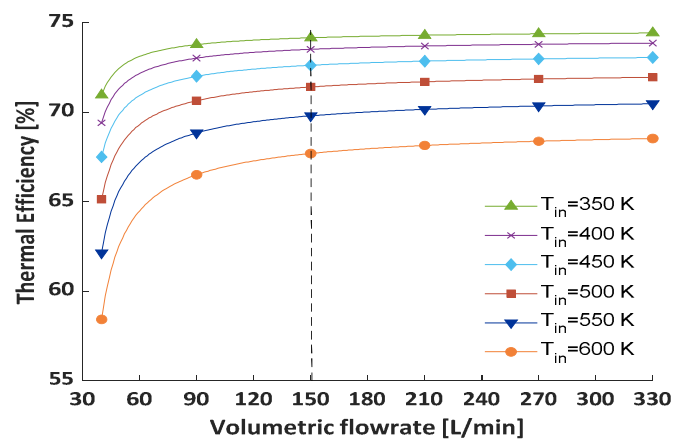

Fig. 6. Thermal efficiency attitude versus variable volume flow-rate for different inlet temperature

Fig. $7 a$ - Fig. $7 d$ present the description of the thermal conductivity, density, specific heat capacity and dynamic viscosity with variable inlet temperature (350$650 \mathrm{~K}$ ) and volume concentrations $1-5 \%$ for all TFs. Basically, the main results showed an increase in the thermal conductivity, viscosity, and density of all nanofluid concentrations compared with Syltherm-800. While on another hand, a specific heat capacity of the nanofluid concentrations presented opposite effect compared with base fluid. Moreover, the nanofluid thermal properties behavior varied between different concentrations and showed high variation at high volume concentration.

The change in the thermal properties of the nanofluid has a positive attitude reflected in the thermal performance of the PTC. Fig. 8 and Fig. 9 illustrate the effect of the thermal properties in the dimensionless Nusselt number and convective heat transfer coefficient, respectively.

Fig. 8 presents the Tungsten oxide nanofluid impact in the dimensionless Nusselt number compared with the base fluid. The results showed an increase in Nusselt number with increasing inlet temperature and nanofluid volume concentrations. For more details, Nusselt number of the base fluid increased from 178.9 up to 620.7 for the temperatures range from 350 - $650 \mathrm{~K}$ while increased from 187.23 up to 667.798 for the $\mathrm{WO}_{3}$ nanofluid at volume concentration equal 5\%. This leaded to maximum enhancement ratio equal $7.6 \%$. This enhancement can be justified according the thermal properties effect in the Nusselt number definition.

Fig. 9 illustrates the convective heat transfer coefficient of the Tungsten oxide nanofluid as well as Syltherm 800 versus variable inlet temperature and volume concentrations. The results showed an increase in the convective coefficient with increasing volume concentration and the temperature. The maximum results were obtained at temperature approximately equal $575 \mathrm{~K}$. This referred to a decrease of the thermal conductivity enhancement rate after this temperature. So the maximum convective heat transfer coefficient reached $833 \mathrm{~W} / \mathrm{m}^{2} . \mathrm{K}$ for $\mathrm{WO}_{3}$ nanofluid at $5 \%$ volume concentration while reached $650 \mathrm{~W} / \mathrm{m}^{2} . \mathrm{K}$ for the base fluid under enhancement ratio equal $28.15 \%$. Regarding to this value, the enhancement in the convection coefficient is greater than the enhancement in the dimensionless Nusselt number referred to the mean definition of this coefficient, which is equal $N u^{*} k / d_{r, i n}$. 


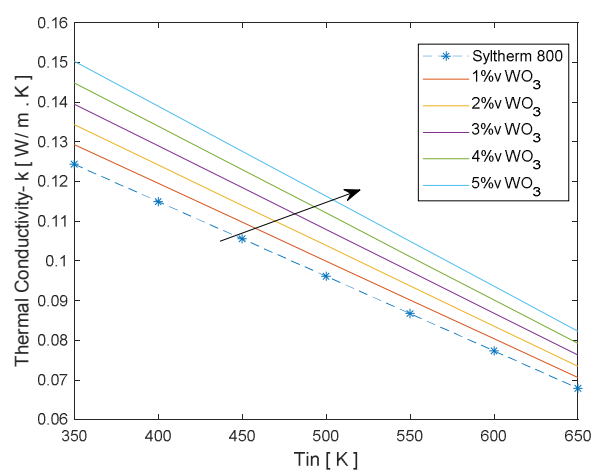

a) Thermal conductivity

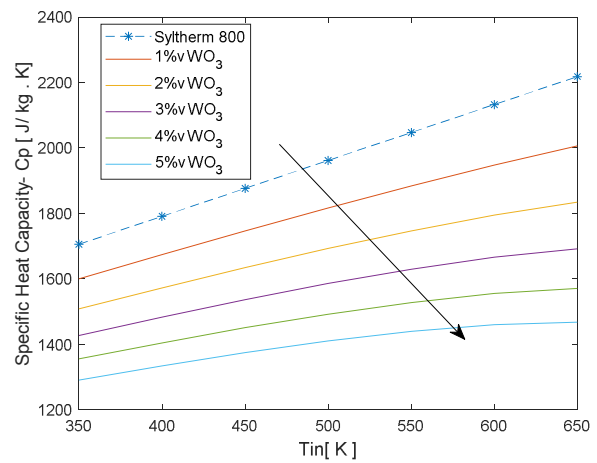

c) Specific heat capacity

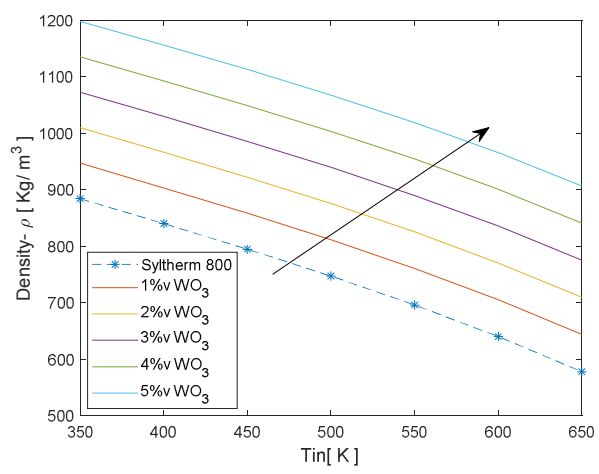

b) Density

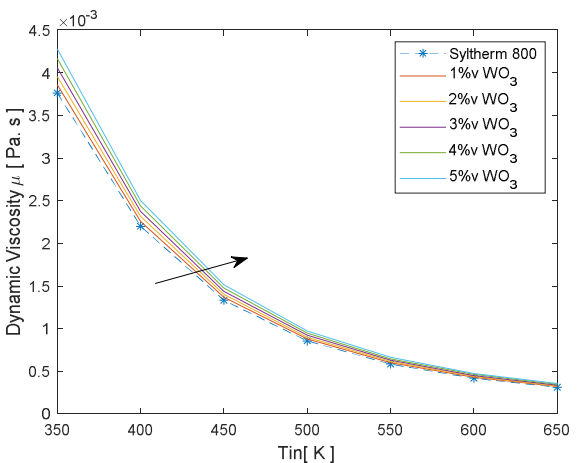

d) Dynamic viscosity

Fig. 7. Thermal properties trends with variable inlet temperatures and volume concentrations

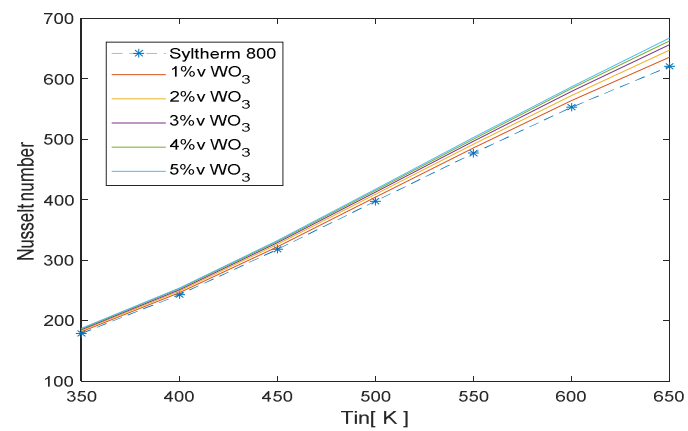

Fig. 8. Nusselt number versus inlet temperatures for different volume concentrations of $\mathrm{WO}_{3} /$ Syltherm 800 nanofluid

Pollack Periodica 15, 2020, 2 


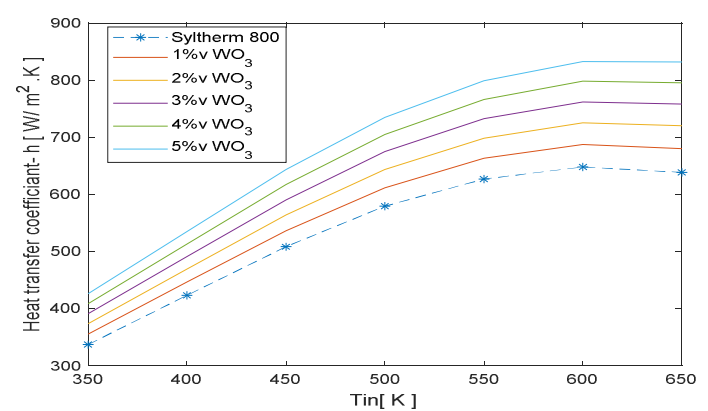

Fig. 9. Convective heat transfer coefficient versus inlet temperatures for different volume concentrations of $\mathrm{WO}_{3}$ /Syltherm 800 nanofluid

Finally, the enhancement results of the dimensionless Nusselt number and convective coefficient lead increase the thermal efficiency and the outlet temperature of the nanofluids. So, Fig. 10 illustrates the thermal efficiency results for different volume concentration of the $\mathrm{WO}_{3}$ nanoflid with variable inlet temperature. The results showed decrease in the thermal efficiency with increasing temperature, while showed increasing in the thermal efficiency with the volume concentration. The major results showed slightly enhancement at high-level temperature and high volume concentration reached $0.66 \%$.

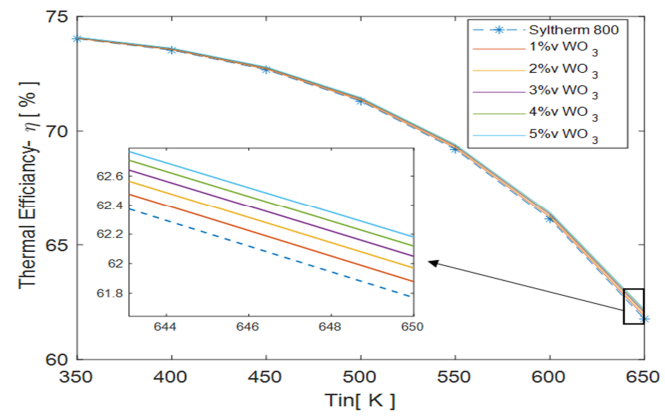

Fig. 10. Thermal efficiency versus inlet temperatures for different volume concentrations of $\mathrm{WO}_{3} /$ Syltherm 800 nanofluid

\section{Conclusion}

In this paper, inserting $\mathrm{WO}_{3} /$ Syltherm- 800 as a new modified nanofluid was used to improve the thermal performance of commercial PTC type LS2 under variable volume concentrations and temperatures. Moreover, this improvement, analyzed under the maximum obtained radiation intensity of Amman, was the maximum value $998.7 \mathrm{~W} / \mathrm{m}^{2}$. Finally, the enhancement in the thermal performance of this PTC was presented and compared with base fluid, where the obtained results showed high enhancement at high volume concentration reached $7.6 \%$ and $28.15 \%$ for the dimensionless Nusselt number 
and convective heat transfer coefficient, respectively, while the thermal efficiency showed slightly enhancement reached $0.66 \%$.

\section{Open Access statement}

This is an open-access article distributed under the terms of the Creative Commons Attribution 4.0 International License (https://creativecommons.org/licenses/by/4.0/), which permits unrestricted use, distribution, and reproduction in any medium, provided the original author and source are credited, a link to the CC License is provided, and changes - if any - are indicated. (SID_1)

\section{References}

[1] Caló A., Pongrácz E. The role of smart energy networks to support the application of waste-to-energy technologies, Pollack Periodica, Vol. 9, Supplement 1, 2014, pp. 61-73.

[2] Jaber J. O., Elkarmi F., Alasis E., Kostas A. Employment of renewable energy in Jordan: Current status, SWOT and problem analysis, Renewable and Sustainable Energy Reviews, Vol. 49, 2015, pp. 490-499.

[3] Duffie J. A., Beckman W. A. Solar engineering of thermal processes, John Wiley, 2013.

[4] Fernández-García A., Zarza E., Valenzuela L., Pérez M. Parabolic-trough solar collectors and their applications, Renewable and Sustainable Energy Reviews, Vol. 14, No. 7, 2010, pp. 1695-1721.

[5] Akbarzadeh S., Valipour M. S. Heat transfer enhancement in parabolic trough collectors: A comprehensive review, Renewable and Sustainable Energy Reviews, Vol. 92, 2018, pp. 198-218.

[6] Sajid M. U., Ali H. M. Recent advances in application of nanofluids in heat transfer devices: A critical review, Renewable and Sustainable Energy Reviews, Vol. 103, 2019, pp. 556-592.

[7] Bellos E., Tzivanidis C., Tsimpoukis D. Enhancing the performance of parabolic trough collectors using nanofluids and turbulators, Renewable and Sustainable Energy Reviews, Vol. 91, 2018, pp. 358-375.

[8] Kamel M. S., Lezsovits F. Simulation of nanofluids laminar flow in a vertical channel, Pollack Periodica, Vol. 13, No. 2, 2018,147-158.

[9] Coccia G., Di Nicola G., Colla L., Fedele L., Scattolini M. Adoption of nanofluids in lowenthalpy parabolic trough solar collectors: numerical simulation of the yearly yield, Energy Conversion Management, Vol. 118, 2016, pp. 306-319.

[10] Rehan M. A., Ali M., Sheikh N. A., Khalil M. S., Chaudhary G. Q., ur Rashid T., Shehryar M. Experimental performance analysis of low concentration ratio solar parabolic trough collectors with nanofluids in winter conditions, Renewable Energy, Vol. 118, 2018, pp. $742-751$.

[11] Subramani J., Nagarajan P. K., Wongwises S., El-Agouz S. A., Sathyamurthy R. Experimental study on the thermal performance and heat transfer characteristics of solar parabolic trough collector using $\mathrm{Al} 2 \mathrm{O} 3$ nanofluids, Environmental Progress and Sustainable Energy, Vol. 37, No. 3, 2018, pp. 1149-1159.

[12] Alsaady M., Fu R., Yan Y., Liu Z., Wu S., Boukhanouf R. An experimental investigation on the effect of ferrofluids on the efficiency of novel parabolic trough solar collector under laminar flow conditions, Heat Transfer Engineering, Vol. 40, No. 9-10, 2019, pp. 753-761. 
[13] Ghasemi S. E., Ranjbar A. A. Thermal performance analysis of solar parabolic trough collector using nanofluid as working fluid: A CFD modelling study, Journal of Molecular Liquids, Vol. 222, 2016, pp. 159-166.

[14] Kasaiean A., Sameti M., Daneshazarian R., Noori Z., Adamian A., Ming T. Heat transfer network for a parabolic trough collector as a heat collecting element using nanofluid, Renewable Energy, Vol. 123, 2018, pp. 439-449.

[15] Bellos E., Tzivanidis C. Thermal analysis of parabolic trough collector operating with mono and hybrid nanofluids, Sustainable Energy Technologies and Assessments, Vol. 26, 2018, pp. 105-115.

[16] Bellos E., Tzivanidis C. Thermal efficiency enhancement of nanofluid-based parabolic trough collectors, Journal of Thermal Analysis Calorimetry, Vol. 135, No. 1, 2019, pp. 597-608.

[17] Basbous N., Taqi M., Janan M. A. Thermal performances analysis of a parabolic trough solar collector using different nanofluids, International Renewable and Sustainable Energy Conference, Marrakech, Morocco, 14-17 November 2016, pp. 322-326.

[18] Ferraro V., Settino J., Cucumo M. A., Kaliakatsos D. Parabolic trough system operating with nanofluids: comparison with the conventional working fluids and influence on the system performance, Energy Procedia, Vol. 101, 2016, pp. 782-789.

[19] Bellos E., Tzivanidis C. Parametric investigation of nanofluids utilization in parabolic trough collectors, Thermal Science and Engineering Progress, Vol. 2, 2017, pp. 71-79.

[20] Toghyani S., Baniasadi E., Afshari E. Thermodynamic analysis and optimization of an integrated Rankine power cycle and nanofluid based parabolic trough solar collector, Energy Conversion and Management, Vol. 121, 2016, pp. 93-104.

[21] Dudley V. E., Evans L. R., Matthews C. W. Test results, industrial solar technology parabolic trough solar collector, Technical Report, Sandia National Labs, Albuquerque, NM, United States, 1995.

[22] Maleki S. A. M., Hizam H., Gomes C. Estimation of hourly, daily and monthly global solar radiation on inclined surfaces: Models re-visited, Energies, Vol. 10, No. 1, 2017, pp. 134-162.

[23] Li P., Zhang D., Xie Y. Heat transfer and flow analysis of Al2O3-water nanofluids in microchannel with dimple and protrusion, International Journal of Heat and Mass Transfer, Vol. 73, 2014, pp. 456-467.

[24] Zhou S. Q, Ni R. Measurement of the specific heat capacity of water-based Al 2 O 3 nanofluid, Applied Physics Letters, Vol. 92, No. 9, 2008, paper No. 093123.

[25] Yu W., Choi S. U. S. The role of interfacial layers in the enhanced thermal conductivity of nanofluids: A renovated Maxwell model, Journal of Nanoparticle Research, Vol. 5, No. 1-2, 2003, pp. 167-171.

[26] Brinkman H. C. The viscosity of concentrated suspensions and solutions, The Journal of Chemical Physics, Vol. 20, No. 4, 1952, page 571.

[27] Mwesigye A., Huan Z. Thermal and thermodynamic performance of a parabolic trough receiver with Syltherm800-A12O3 nanofluid as the heat transfer fluid, Energy Procedia, Vol. 75, 2015, pp. 394-402.

[28] Sharafeldin M. A., Gróf G. Efficiency of evacuated tube solar collector using WO3/Water nanofluid, Renewable Energy, Vol. 134, 2019, pp. 453-460. 